\title{
Response of Pale Swallow-wort, Vincetoxicum rossicum, following Aboveground Tissue Loss: Implications for the Timing of Mechanical Control
}

\author{
Curtis I. McKague* and NAOMI CAPPUCCINO
}

Department of Biology, Carleton University, Ottawa, Ontario K1S 5B6 Canada

*Author for correspondence; Current address: Department of Integrative Biology, University of Guelph, Guelph, Ontario, N1G 2W1 Canada; Telephone: 519-824-4120 X 56307; e-mail address: cmckague@uoguelph.ca

McKague, Curtis I., and Naomi Cappuccino. 2005. Response of Pale Swallow-wort, Vincetoxicum rossicum, following aboveground tissue loss: implications for the timing of mechanical control. Canadian Field-Naturalist 119(4): 525-531.

The growth and reproduction of Pale Swallow-wort, Vincetoxicum rossicum, were investigated following differentially timed above-ground tissue loss by clipping throughout the growing season in Ottawa, Canada. If clipping occurred early in the growing season (before June), mature plants were able to compensate in height but not in biomass or reproductive output when compared to uncut controls. This compensation in height did not seem to come at the expense of below-ground storage tissue; there was no significant difference in root mass among the control and treatment conditions. Final plant height, mass, and reproduction declined as plants were cut later in the season. Pale Swallow-wort seedlings clipped before June were able to compensate in height when compared to uncut controls. Unlike mature plants, this compensation in height did come at the expense of root mass. As the clipping treatment was performed later into the growing season, both final plant height and shoot mass decreased, while root mass increased. The best time for controlling the population spread of Pale Swallow-wort using a single cutting treatment was on or near 26 June. Plants cut earlier than this date were able resprout and produce seeds; those cut after had already produced seeds that appeared viable and may be able to germinate if the cut stems were left in the field. When a single cutting or mowing treatment is to be employed for controlling Pale Swallow-wort, we recommend cutting after the first fruits are produced but before they are fully developed.

Key Words: Pale Swallow-wort, Dog-strangling Vine, Vincetoxicum rossicum, Cynanchum rossicum, mechanical control, invasive plants, Ottawa.

Pale Swallow-wort, Vincetoxicum rossicum Kleo. Barb. (Asclepiadaceae; synonym Cynanchum rossicum), also known as Dog-strangling Vine, is an introduced plant species that is becoming an increasingly problematic weed of natural areas in the northeastern United States and Ontario. Native to Ukraine and Russia, Pale Swallow-wort was introduced into North America in the late 1800s (Sheeley and Raynal 1996). Pale Swallow-wort has been documented across southern Ontario from Toronto to Ottawa (DiTommaso et al. 2005), and has recently spread across the Ottawa River into the Outaouais region of Quebec and has been located in Montreal (DiTommaso et al. 2005). Within the United States, Pale Swallow-wort is widely distributed within New York State, and has also been documented in Connecticut, Indiana, Massachusetts, Michigan, New Hampshire, New Jersey, and Pennsylvania (DiTommaso et al. 2005).

Pale Swallow-wort (Figure 1) is a perennial herbaceous vine, with stem lengths of mature individuals ranging from $60-250 \mathrm{~cm}$ (DiTommaso et al. 2005). Stems are often intertwined within dense patches while individual plants climb upon other vegetation for structural support. Leaves are ovate and acute at the tip and are opposite in arrangement (DiTommaso et al. 2005). Flowers are pink to red in coloration, $5-7 \mathrm{~mm}$ in diameter, and have five fleshy petals arranged in a star configuration. Fruits, often arranged in pairs, are slender follicles 4-7 cm long (St. Denis and Cappuccino 2004; DiTommaso et al. 2005). In late summer, follicles release wind-dispersed comose seeds which are $3-5 \mathrm{~mm}$ in length (DiTommaso et al. 2005).

Pale Swallow-wort is capable of thriving under various environmental conditions and has been documented in numerous habitat types, including lawns, gardens, old fields, disturbed areas, and along both coniferous and deciduous forest edges as well as within their understoreys (Sheeley and Raynal 1996; DiTommaso et al. 2005). Pale Swallow-wort thrives on limestonebased soils and is invading globally rare alvar habitats on the limestone plains of northern New York State (DiTommaso et al. 2005 and personal observation). Once established, populations of Pale Swallow-wort grow densely and spread aggressively, often eliminating native plants (Sheeley and Raynal 1996; Christensen 1998). Competitive displacement of native plant species by Pale Swallow-wort may have negative consequences for local faunal. Ernst and Cappuccino (2005) found that diversity and abundance of both stem- and ground-dwelling arthropod species were substantially lower in patches of Pale Swallow-wort than in patches of native old-field plant species (Asclepias syriaca, Solidago altissima, and mixed graminoids). Pale Swallow-wort is also detrimental to the Monarch butterfly (Danaus plexippus) which has been observed ovipositing on it rather than on milkweed (Asclepias syriaca), 
its usual plant host, resulting in larval death (Mattila and Otis 2003).

Although Pale Swallow-wort is not listed in any federal or provincial/state weed or seed acts in Canada or the United States (DiTommaso et al. 2005), it is recognized as a noxious weed and control programs are initiated at the municipal level. Attempting to control the spread of Pale Swallow-wort is a difficult task. It is self-compatible, so a single propagule can initiate a new infestation (St. Denis and Cappuccino 2004). Individual plants produce large numbers of viable seeds, which require neither dormancy nor stratification (Christensen 1998). Seedling survivorship is very high, ranging from 70 to 100\% (Ladd and Cappuccino, in press). Seeds are polyembryonic (Sheeley and Raynal 1996; St. Denis and Cappuccino 2004), producing multiple seedlings about half the time (Cappuccino et al. 2002).

Options for controlling Swallow-wort are limited. Herbicides such as glyphosate are moderately effective; however, several applications are needed (Christensen 1998; Lawlor and Raynal 2002). A growing number of communities are banning herbicides due to their toxicity to humans and non-target organisms (DiTomaso 1997); in these places, manual means of controlling Swallow-wort are necessary. Repeated mowing can be an effective way to diminish the seed crop, but it does not kill the plants which resprout from buds at the root crown (Christensen 1998; DiTommaso et al. 2005). Moreover, mowing may not be feasible where equipment and labour are limiting. Mowing areas that are not monotypic stands of Pale Swallow-wort may alter the structure of the native plant community, which may be detrimental to insect populations (DiTomaso 1997).

For smaller infestations of Pale Swallow-wort, selectively clipping individuals may be a more ecologically effective solution. If available resources dictate that only a single cut is to be made, the timing of that cut is critical in determining whether seed production will be prevented. In general, plants clipped early in the growing season are more likely to compensate in growth and/or reproduction (Maschinski and Whitham 1989; Bergelson and Crawley 1992; Mutikainen et al. 1994; Bergelson et al. 1996; Lennartsson et al. 1998). If clipping occurs later in the growing season, plants often have insufficient time for compensatory growth. A late-season cut may thus seem preferable; however, seeds already produced by the plant may be viable if the cut stems are left at the site or scattered by a mower.

The present study was performed to better understand the growth and reproductive responses of Pale Swallow-wort following aboveground tissue loss by clipping at different times throughout the growing season. From this increased understanding in Pale Swallow-wort biology, we hope that ecologically friendly and effective control methods may be used to slow the population growth of this species, thereby minimizing its deleterious effects on natural habitats.

\section{Study Area and Methods}

Response of mature plants to differentially timed

aboveground tissue loss

This experiment was performed in an old field/forest edge habitat in Hog's Back Park, Ottawa, Ontario $\left(45^{\circ} 22.45^{\prime} \mathrm{N}, 75^{\circ} 41.65^{\prime} \mathrm{W}\right)$, from May-August 2003. In mid-May, 150 individual plants of Vincetoxicum rossicum with initial heights of $30.2 \pm 0.2 \mathrm{~cm}$ (mean $\pm \mathrm{SE}$ ) were measured and randomly assigned to one of five differentially timed clipping treatments, or to the uncut control condition. Initially, 25 plants were assigned to each treatment; however, some plants were lost during the course of this experiment due to damage by humans or other animals.

Beginning on 29 May, all plant heights were measured and flower or fruit formation was noted. The first clipping treatment was performed this day. Clipping involved cutting the plants at ground level. Cut plants were dried for three days in a drying oven at $60^{\circ} \mathrm{C}$ and weighed. Subsequent clipping treatments were performed every two weeks until the final clipping treatment on 24 July. Plant heights were recorded on each clipping date and again on 7 and 21 August. Aboveand below-ground tissues for all plants were harvested on 21 August and dried for three days in the drying oven. Roots and shoots were weighed separately for each plant. Any seeds that were produced were counted.

\section{Response of seedlings to differentially timed above- ground tissue loss}

A similar experiment was performed in an enclosed old field setting on Carleton University property in Ottawa, Ontario $\left(45^{\circ} 23.023^{\prime} \mathrm{N}, 75^{\circ} 41.553^{\prime} \mathrm{W}\right)$ from May-August 2003. During April 2003, V. rossicum plants were grown from seed in a greenhouse at Carleton University. In mid-May, 150 of these seedlings with initial heights of $18.0 \pm 0.4 \mathrm{~cm}($ mean \pm SE) were transplanted into the old field after a two-week outdoor acclimatization period. Seedlings were randomly assigned to the same clipping treatments described above for mature plants.

\section{Statistical Analyses}

All statistical analyses were performed using SPSS 11.5 for Windows (standard base version). Pre-treatment heights for both adult plants and seedlings in the different treatments were compared using one-way ANOVAs. Because the assumptions of parametric statistics were not met, Kruskal-Wallis tests were used to investigate among-treatment differences in final heights, shoot mass, and root mass for both adult plants and seedlings, as well as the seed output of adult plants. When a statistically significant difference was observed among treatments, a Games-Howell post-hoc test, which allows for unequal variance and unequal sample size, was performed to determine which treatments differed from one another (Games and Howell 1976). 


\section{Results}

Response of mature plants to differentially timed above-ground tissue loss

Pre-treatment heights did not differ significantly among the treatments (ANOVA, $\mathrm{F}_{5,144}=1.754$, $P=0.126$ ). The time of the growing season when plants were cut had a significant effect on final height (Kruskal-Wallis, $\mathrm{H}=85.786 \mathrm{df}=5, \mathrm{P}<0.001$ ). The Games-Howell post-hoc test revealed that plants that were cut on 29 May were able to compensate in height; they were not significantly different in height from the uncut controls (Figure 2). The final heights of plants cut on 29 May, 12 and 26 June were not significantly different from one another but they did differ from both 10 and 24 July treatments. The 10 and 24 July treatment plants were not significantly different from one another but they did differ significantly from all other treatment groups in the experiment including uncut controls.

The timing of the cut did not have a significant effect on root mass (Figure 3, Kruskal-Wallis, $\mathrm{H}=6.123$ $\mathrm{df}=5, \mathrm{P}=0.294$ ), while shoot mass did differ significantly among treatments (Kruskal-Wallis, $\mathrm{H}=96.952$ $\mathrm{df}=5, \mathrm{P}<0.001)$. The Games-Howell post-hoc test revealed that none of the experimentally clipped plant groups were able to compensate in shoot mass; all clipping treatments weighed significantly less than the uncut control. Plants cut on 29 May, 12 and 26 June were not significantly different from one another but they

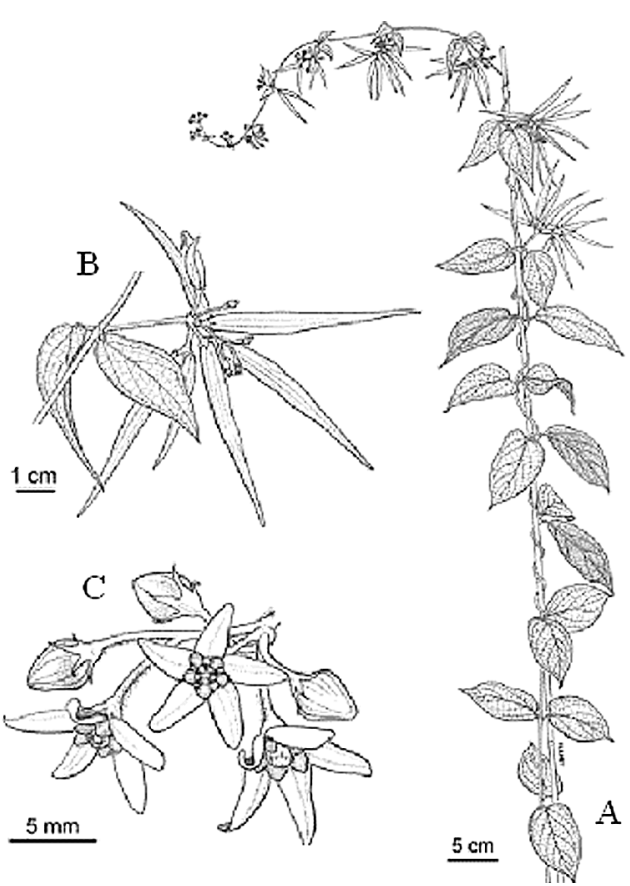

FIGURE 1. Pale Swallow-wort, Vincetoxicum rossicum. A. An individual plant characteristically climbing substrate for structural support; B. Leaves and fruits; C. Inflorescences showing buds and mature flowers (Figure borrowed from DiTommaso et al. 2005, with permission from the authors and Canadian Journal of Plant Science).

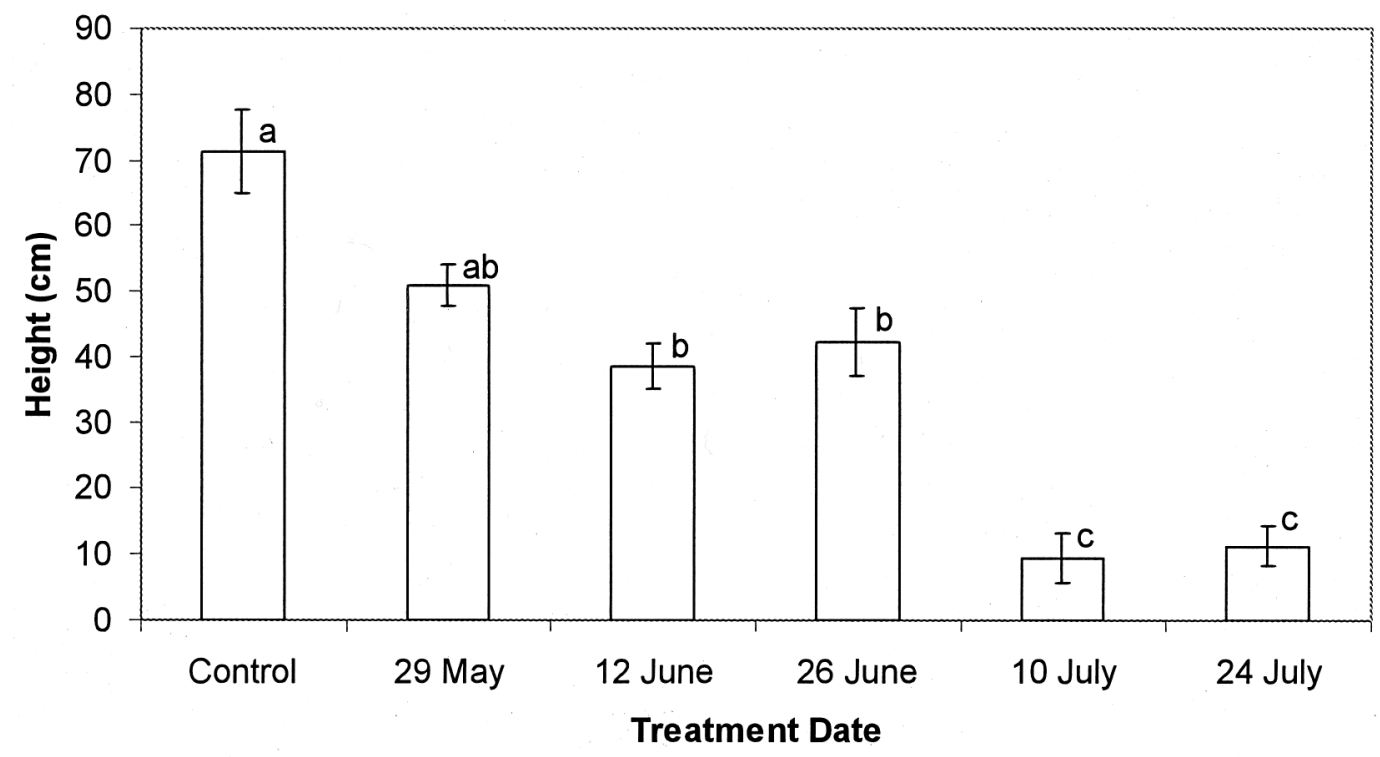

Figure 2. Final height of mature Pale Swallow-wort plants clipped on various dates. Values are means \pm SE. Clipping date had a significant effect on plant mean height (Kruskal-Wallis test, $\mathrm{H}=85.786$, $\mathrm{df}=5, \mathrm{P}<0.001$ ). Ranked means that were significantly different $(\mathrm{P}<0.05)$ according to Games and Howell's $(1976)$ multiple comparisons test are assigned different letters. 


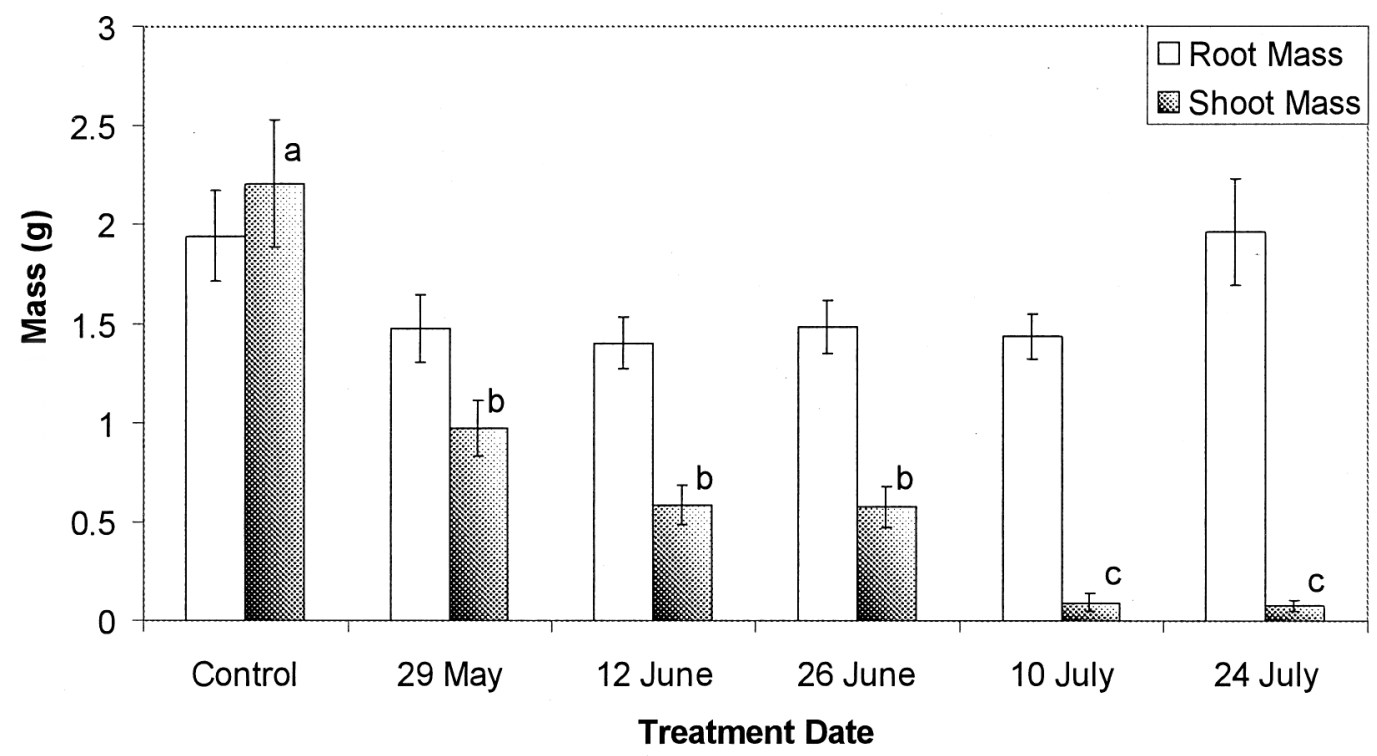

FIGURE 3. Final root and shoot mass of mature Pale Swallow-wort plants clipped on various dates. Values are means \pm SE. Clipping date had a significant effect on mean shoot mass (Kruskal-Wallis test, $\mathrm{H}=96.952, \mathrm{df}=5, \mathrm{P}<0.001)$ but there was no difference in mean root mass among treatments (Kruskal-Wallis test, $\mathrm{H}=6.123$, $\mathrm{df}=5, \mathrm{P}=0.294$ ). Ranked means that were significantly different $(\mathrm{P}<0.05)$ according to Games and Howell's $(1976)$ multiple comparisons test are assigned different letters.

did differ from both 10 and 24 July treatments. The 10 and 24 July treatment plants were not significantly different from one another but they did differ significantly from all other treatment groups.

Seed production was greatly affected by clipping treatments (Table 1). Experimentally cut plants showed a significant decline in their reproductive output in comparison to uncut controls (Kruskal-Wallis, $\mathrm{H}=50.107$ $\mathrm{df}=5, \mathrm{P}<0.001)$. The Games-Howell post-hoc test revealed that the clipping treatments were not significantly different from one another. No fruit production was observed until 26 June, and those plants that produced seeds despite having been clipped (29 May and 12 June cutting treatments) did so by 24 July and 7 August, respectively. Plants cut on or after 26 June failed to produce any seeds.

\section{Response of seedlings to differentially timed above-} ground tissue loss

Seedlings in the six treatments did not differ significantly in initial height (ANOVA, $\mathrm{F}_{5,144}=0.480$, $\mathrm{P}=0.791$ ). The timing of clipping had a significant effect on their final height (Kruskal-Wallis, $\mathrm{H}=66.931$ $\mathrm{df}=5, \mathrm{P}<0.001)$. The Games-Howell post-hoc test revealed that plants that were cut on 30 May were able to compensate in height as they were not significantly different in height from the uncut controls (Figure 4). Plants cut on 13 and 27 June, and 11 and 25 July were significantly smaller at the end of the season than those in the control treatment and the 30 May treatment.

The time of the growing season when seedlings were cut had a significant effect on root mass (Figure 5, Kruskal-Wallis, $\mathrm{H}=21.013 \mathrm{df}=5, \mathrm{P}=0.001)$.

TABLE 1. Seed production of mature Pale Swallow-wort plants clipped on various dates. Number of seeds per plant are group means with $\mathrm{SE}$ in parentheses. Clipping date had a significant effect on reproductive output (Kruskal-Wallis test, $\mathrm{H}=$ 50.107, $\mathrm{df}=5, \mathrm{P}<0.001)$. Treatments with significantly different $(\mathrm{P}<0.05)$ seed production according to Games and Howell's (1976) multiple comparisons test are assigned different letters.

\begin{tabular}{lcccc}
\hline \hline Treatment Group & $\mathrm{n}$ & Proportion producing seed & Number of seeds per plant \\
\hline Control & 27 & 0.56 & 47.2 & $(13.2)^{\mathrm{a}}$ \\
29 May & 24 & 0.13 & 5.4 & $(3.3)^{\mathrm{b}}$ \\
12 June & 22 & 0.14 & 2.3 & $(1.4)^{\mathrm{b}}$ \\
26 June & 23 & 0.00 & 0.0 & $(0.0)^{\mathrm{b}}$ \\
10 July & 24 & 0.00 & 0.0 & $(0.0)^{\mathrm{b}}$ \\
24 July & 24 & 0.00 & 0.0 & $(0.0)^{\mathrm{b}}$ \\
\hline \hline
\end{tabular}




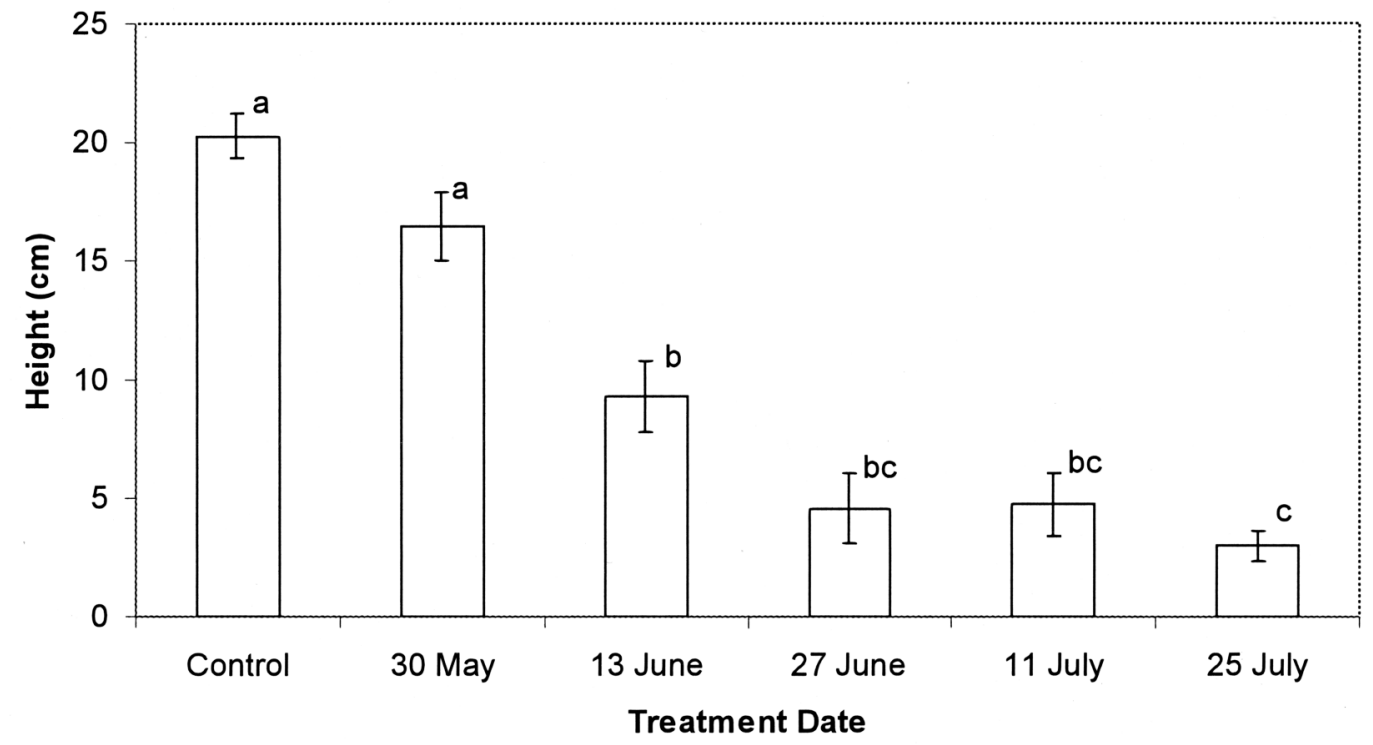

FIGURE 4. Final height of Pale Swallow-wort seedlings clipped on various dates. Values are means \pm SE. Clipping date had a significant effect on plant mean height (Kruskal-Wallis test, $\mathrm{H}=66.931$, df $=5, \mathrm{P}<0.001$ ). Ranked means that were significantly different $(\mathrm{P}<0.05)$ according to Games and Howell's (1976) multiple comparisons test are assigned different letters.

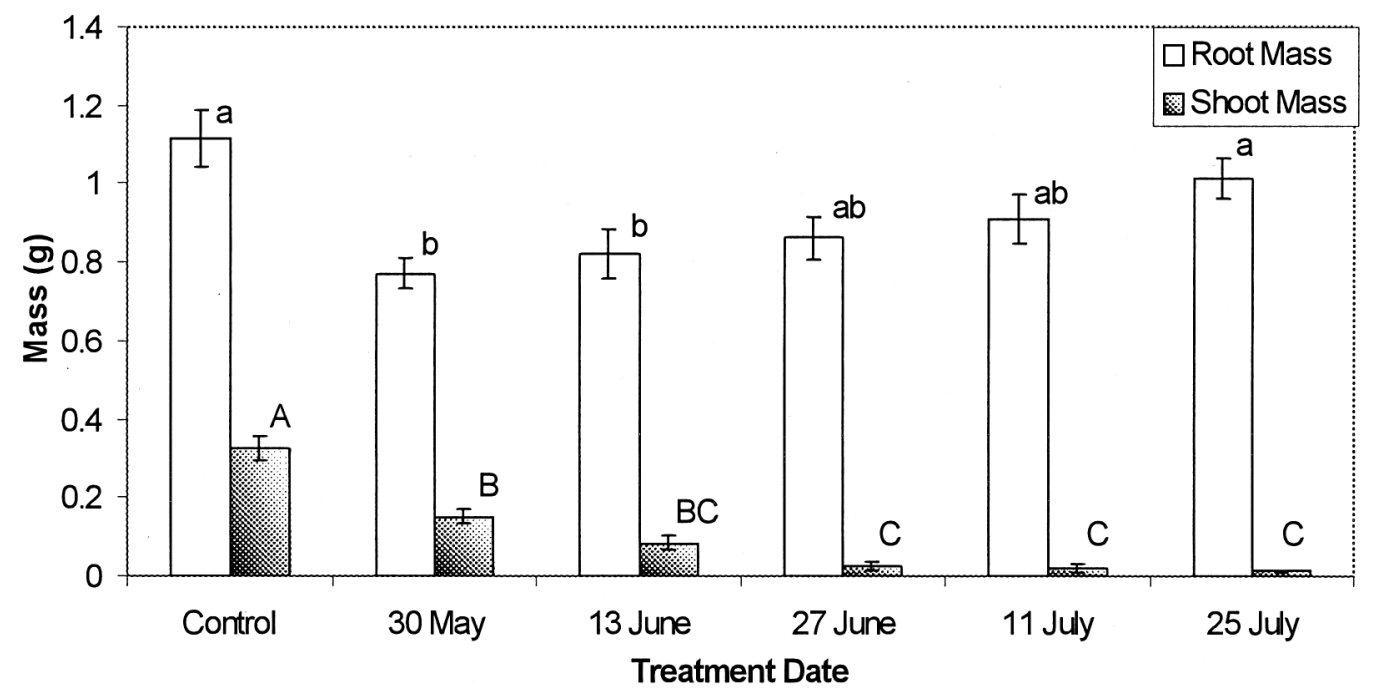

FIGURE 5. Final root and shoot mass of Pale Swallow-wort seedlings clipped on various dates. Values are means \pm SE. Clipping date had a significant effect on mean shoot mass (Kruskal-Wallis test, $\mathrm{H}=68.644, \mathrm{df}=5, \mathrm{P}<0.001$ ) and on mean root mass (Kruskal- Wallis test, $\mathrm{H}=21.013, \mathrm{df}=5, \mathrm{P}=0.001$ ). Ranked means of shoot mass that were significantly different $(\mathrm{P}<0.05)$ according to Games and Howell's (1976) multiple comparisons test are assigned different uppercase letters while ranked means of root mass that were significantly different $(\mathrm{P}<0.05)$ according to Games and Howell's (1976) multiple comparisons test are assigned different lowercase letters. 
Root mass was lowest for the 30 May treatment group and scores tended to increase in value as plants were cut later in the season. Final shoot mass also differed significantly among treatment groups (Figure 5, Kruskal-Wallis, $\mathrm{H}=68.644 \mathrm{df}=5, \mathrm{P}<0.001)$. The GamesHowell post-hoc test revealed that none of the experimentally clipped plant groups were able to compensate in shoot mass; all clipping treatments differed significantly from the controls. No seedlings produced flowers or seeds.

\section{Discussion}

When the stems of Pale Swallow-wort are cut during the growing season, new shoots emerge from buds at the root crown. In the present study, in which primary shoots were cut at two-week intervals throughout the growing season, Pale Swallow-wort plants resprouted, but were not able to compensate fully for tissue loss. As we expected from the results of previous studies on other plant species (e.g., Maschinski and Whitham 1989; Bergelson and Crawley 1992; Mutikainen et al. 1994; Bergelson et al. 1996; Lennartsson et al. 1998), the ability of Pale Swallow-wort to partially compensate for tissue loss declined as plants were clipped progressively later in the growing season. Although plants cut on 29-30 May appeared to compensate in height, by the end of the growing season the new shoots had not attained the same biomass as the primary shoots produced by the uncut controls.

While the root mass of mature Pale Swallow-wort plants showed no significant effect of above-ground tissue removal, the clipping treatment significantly diminished the root mass of the seedlings. Seedlings lack the extensive root system of the mature plants, and their partial compensation in height and biomass seemed to come at the expense of their roots. All seedlings in our experiment survived until the end of August. However, in a summer with less rainfall than 2003, the reallocation of resources from root to shoot following clipping could leave the seedlings with underdeveloped root systems incapable of sustaining the plant through a drought (e.g., Bilbrough and Richards 1993; Perkins and Owens 2003).

Mature control plants allocated nearly half their biomass to roots, a high proportion for mid- to latesuccessional species (Parrish and Bazzaz 1982). The high root:shoot ratio is partly explained by the weakness of the stem of this vine-forming plant; stems that have not twined around neighbouring vegetation generally cannot support the weight of the fruits and flop to the ground once fruit production is underway. However, the plant also possesses an extensive fibrous root system with a thick, woody rootstock, which likely contributes to its apparent ability to outcompete native vegetation and persist for decades (Sheeley and Raynal 1996). Seedling root:shoot ratios were even higher; control seedlings invested over three times more tissue into root mass versus shoot mass. The seedlings appeared to be developing below-ground storage tissue in preparation for future growing seasons. This may explain the slow maturation of Pale Swallow-wort; in a separate experiment, individuals planted as seeds four years ago have yet to flower (N. Cappuccino, unpublished data).

Seed production was reduced dramatically by clipping. Clipping on or after 26 June halted seed production entirely. Clipping earlier in the season was insufficient to completely control reproductive output; over $10 \%$ of the plants clipped on 29 May and 12 June produced seeds. Fruits were first observed on 26 June in the controls and the three treatments that had not previously been cut. A single clipping treatment during this period of the growing season would be most effective because the fruits on this date contained only immature seeds that would be unable to germinate if left in the field following clipping. Plants clipped on or after 10 July also failed to produce seeds following clipping, but prior to clipping, their fruits contained seeds that appeared to be mature (they were filled and darkening in preparation for release). Although our data suggest that clipping in late June would be most effective, the timing of fruit production in other years and at other sites may vary. We recommend that plants be monitored for fruit formation and that cutting take place when the first fruits are formed but not fully developed.

Mechanical control by clipping can be a successful method for controlling localized patches of Pale Swallow-wort that are threatening native species. However, the ability of the plant to regrow following aboveground tissue loss both underscores the need for a more sustainable means of controlling this invasive weed, such as biological control, and argues against introducing a leaf-chewing herbivore as the sole control agent. Adequate control of target plants following the introduction of a single herbivore is the exception rather than the rule (Julien 1989) and success is often achieved only after introduction of several herbivores (Denoth et al. 2002) that damage the plant in complementary ways (James et al. 1992). Damaging the target plant in complementary ways can also be achieved through integrated weed management, for example, by combining mechanical control with biological control (Paynter and Flanagan 2004). Integrated weed management is increasingly being viewed as the most effective strategy for controlling invasive plants in natural areas (Buckley et al. 2004) and is likely our best hope for controlling Pale Swallow-wort.

\section{Acknowledgments}

This research was funded by the Natural Sciences and Engineering Research Council of Canada (Undergraduate Student Research Award to CIM and Discovery Grant to NC). Permit for land access for this experiment was granted by Mike Muir of the National Capital Commission (NCC). The authors wish to thank 
the two anonymous reviewers for their helpful critical reviews of this manuscript; David Carpenter for his assistance in the field; Ed Bruggink for caring for our seedlings; and a special thanks to Jack and Yvonne McKague for their eternal support.

\section{Literature Cited}

Bergelson, J., and M. J. Crawley. 1992. Herbivory and Ipomopsis aggregata: the disadvantages of being eaten. The American Naturalist 139: 870-882.

Bergelson, J., T. Juenger, and M. J. Crawley. 1996. Regrowth following herbivory in Ipomopsis aggregata: compensation but not overcompensation. The American Naturalist 148: 744-755.

Bilbrough, C. J., and J. H. Richards. 1993. Growth of sagebrush and bitterbrush following simulated winter browsing: mechanisms of tolerance. Ecology 74: 481-492.

Buckley, Y. M., M. Rees, Q. Paynter, and M. Lonsdale. 2004. Modelling integrated weed management of an invasive shrub in tropical Australia. Journal of Applied Ecology 41: 547-560.

Cappuccino, N., R. MacKay, and C. Eisner. 2002. Spread of the invasive alien vine Vincetoxicum rossicum: tradeoffs between seed dispersability and seed quality. The American Midland Naturalist 148: 263-270.

Christensen, T. 1998. Swallowworts: the ecology and control of Vincetoxicum spp. Wildflower 14: 21-25.

Denoth, M., L. Frid, and J. H. Myers. 2002. Multiple agents in biological control: improving the odds? Biological Control 24: 20-30.

DiTomaso, J. M. 1997. Risk analysis of various weed control methods. California Exotic Pest Plant Council Symposium Proceedings, 1-6.

DiTommaso, A., F. M. Lawlor, and S. J. Darbyshire. 2005. The biology of invasive alien plants in Canada. 2. Cynanchum rossicum (Kleopow) Borhidi [= Vincetoxicum rossicum (Kleopow) Barbar.] and Cynanchum louiseae (L.) Kartesz \& Gandhi [= Vincetoxicum nigrum (L.) Moench]. Canadian Journal of Plant Sciences 85: 243-263.

Ernst, C. M., and N. Cappuccino. 2005. The effect of an invasive alien vine, Vincetoxicum rossicum (Asclepiadaceae), on arthropod populations in Ontario old fields. Biological Invasions 7: 417-425.

Games, P., and J. Howell. 1976. Pairwise multiple comparison procedures with unequal n's and/or variances: a monte carlo study. Journal of Educational Statistics 1: 113-125.
James, R. R., P. B. McEvoy, and C. S. Cox. 1992. Combining the cinnabar moth (Tyria jacobaeae) and the ragwort flea beetle (Longitarsus jacobaeae) for control of ragwort (Senecio jacobaea): an experimental analysis. Journal of Applied Ecology 29: 589-596.

Julien, M. H. 1989. Biological control of weeds worldwide: trends, rates of success and the future. Biocontrol News and Information 10: 299-306.

Lawlor, F., and D. J. Raynal. 2002. Response of swallowwort to herbicides. Weed Science 50: 179-185.

Lennartsson, T., P. Nilsson, and J. Tuomi. 1998. Induction of overcompensation in the field gentian, Gentianella campestris. Ecology 79: 1061-1072.

Maschinski, J., and T. G. Whitham. 1989. The continuum of plant responses to herbivory: the influence of plant association, nutrient availability, and timing. The American Naturalist 134: 1-19.

Mattila, H. R., and G. W. Otis. 2003. A comparison of the host preference of monarch butterflies (Danaus plexippus) for milkweed (Asclepias syriaca) over dog-strangler vine (Vincetoxicum rossicum). Entomologia Experimentalis et Applicata 107: 193-199.

Mutikainen, P., M. Walls, and A. Ojala. 1994. Sexual differences in responses to simulated herbivory in Urtica dioica. Oikos 69: 397-404.

Parrish, J. A. D., and F. A. Bazzaz. 1982. Responses of plants from three successional communities to a nutrient gradient. Journal of Ecology 70: 233-248.

Paynter, Q., and G. J. Flanagan. 2004. Integrating herbicide and mechanical control treatments with fire and biological control to manage an invasive wetland shrub, Mimosa pigra. Journal of Applied Ecology 41: 615-629.

Perkins, S. R., and M. K. Owens. 2003. Growth and biomass allocation of shrub and grass seedlings in response to predicted changes in precipitation seasonality. Plant Ecology 168: 107-120.

Sheeley, S. E., and D. J. Raynal. 1996. The distribution and status of species of Vincetoxicum in eastern North America. Bulletin of the Torrey Botanical Club 123: 148-156.

St. Denis, M., and N. Cappuccino. 2004. Reproductive biology of Vincetoxicum rossicum (Kleo.) Barb. (Asclepiadaceae), an invasive alien in Ontario. Journal of the Torrey Botanical Society 131: 8-15.

Received 6 July 2004

Accepted 7 December 2005 